\title{
A invenção do eu infantil: dispositivos pedagógicos em ação
}

\author{
Maria Isabel Edelweiss Bujes \\ Universidade Luterana do Brasil, Programa de Pós-Graduação em Educação
}

Como se formou um tipo de governo dos homens
onde não se é exigido simplesmente a obedecer,
mas a manifestar, enunciando-o o que se é?

Foucault apud Larrosa.

Tecnologia do eu e educação. 1994, p. 53.

A discussão que empreendo neste trabalho ${ }^{1}$ faz parte de uma ampla pesquisa ${ }^{2}$ que teve como foco a análise do Referencial Curricular Nacional para a Educação Infantil (Brasil, 1998) e cujo objetivo principal foi o de discutir, com base no arsenal foucaultiano, como se exerce o governamento ${ }^{3}$ da infância.

${ }^{1}$ Agradeço aos colegas e amigos Alfredo Veiga-Neto, João Paulo Pooli, Luís Henrique Sachi Santos e Maria Lúcia Wortmann pela leitura desse meu texto e pelas inestimáveis sugestões.

${ }^{2}$ Trata-se da tese de doutorado denominada Infância e maquinarias (Bujes, 2001), orientada por Alfredo Veiga-Neto, do Programa de Pós-Graduação em Educação da UFRGS.

${ }^{3}$ Utilizo o termo governamento, com a acepção de governação ou governança, no sentido de ato de governar-(se), para distinguir
O Referencial Curricular Nacional para a Educação Infantil - RCN/EI ou, simplesmente, RCN - é um documento de orientação curricular, elaborado sob os auspícios do Ministério da Educação e posto em circulação no início do ano letivo de 1999. Ele "integra a série de documentos dos Parâmetros Curriculares Nacionais" (Brasil, 1988, v. 1, p. 5). É composto de três volumes, denominados: 1. Introdução; 2. Formação Pessoal e Social e 3. Conhecimento do Mundo. O primeiro volume traz informações de âmbito mais geral: faz uma reflexão sobre creches e pré-escolas no Brasil e apresenta concepções sobre criança,

de governo - relacionado à administração superior, como poder executivo que se encarrega da gestão do Estado, por exemplo (Ferreira, 1986). Justifico a utilização do termo (existente no português antigo) a fim de diferenciá-lo de governo - que indicaria tanto uma instância de controle político quanto uma instituição a quem cabe o exercício da autoridade -, para significá-lo como ato que se exerce sobre uma pessoa ou que ela exerce sobre si mesma, para controlar suas ações. Para maiores esclarecimentos ver Bujes (2001); Veiga-Neto (2001). 
educação, instituição de educação infantil e seus profissionais. Esse volume apresenta ainda os objetivos gerais para a educação infantil e a forma como foram organizados os dois outros volumes. O segundo volume tem como conteúdo as questões relativas à formação (o que eu denomino mais adiante de domínio moral). Trata dos processos relativos à constituição da identidade e da autonomia pelas crianças. $\mathrm{O}$ terceiro, que se volta para o que ali se considera conhecimento do mundo - tomado como um âmbito de experiência -, é composto pelos seguintes eixos de trabalho: movimento, música, artes visuais, linguagem oral e escrita, natureza e sociedade e matemática. São 468 páginas, no conjunto dos três volumes, que têm por finalidade orientar as práticas, as discussões e a elaboração dos projetos curriculares voltados para a infância nas instituições educacionais a ela destinadas. Os volumes 2 e 3 , que se incumbem mais diretamente das sugestões de trabalho com as crianças, encontram-se distribuídos pelos eixos de trabalho já referidos, e cada um de tais eixos é apresentado segundo o seguinte esquema: considerações sobre a presença do eixo - música, matemática, linguagem etc. - na educação infantil; a criança e sua relação com aquele eixo - a criança e o movimento, a criança e as artes etc.; objetivos; conteúdos; orientações gerais para o professor - que envolvem sempre a organização do tempo e do espaço e algumas orientações específicas relativas ao trabalho naquele eixo - chamadas, via de regra, de orientações didáticas; e observação, registro e avaliação formativa.

A investigação que deu origem a esse artigo se propôs a tornar mais explícito o caráter instrumental e técnico do RCN, concebendo-o como um meio inventado para colocar em operação uma série de tecnologias que têm por finalidade moldar e modelar as condutas infantis. Além disso, tratou também de apontar como tal propósito está conectado com objetivos políticos mais amplos de gestão social. A perspectiva em que se moveu o estudo, portanto, foi a de enfatizar em suas análises o caráter histórico e político do Referencial. Isso implicou mostrar como as opções nele presentes - que dizem respeito aos saberes que o orientam, aos arranjos que o compõem, aos saberes que põe em marcha, às palavras de ordem que faz ressoar etc. - não passam de escolhas arbitrárias de um grupo social e profissional hegemônico, e são nele incorporadas de tal forma que passam a ser vistas como naturais e não passíveis de discussão. $\mathrm{O}$ acento nesse caráter inventado e a desnaturalização que disso decorre servem exatamente para estabelecer um contraponto com algumas crenças longamente cultivadas, especialmente no campo educativo. Trata-se de crenças que nos prometeram o desenvolvimento, o progresso, a emancipação da humanidade pelo uso correto da razão e pelo cultivo da verdade. Ideais que, aliados aos de autonomia e de cidadania, são algumas das pedrasde-toque do projeto moderno para a educação, e compõem, sem dúvida, a racionalidade que orienta o RCN. E, com relação a esses ideais, talvez fosse aqui interessante lembrar Lyotard, o crítico das metanarrativas modernas, nessas suas palavras da década de 1980 e hoje mais do que atuais:

A modernidade, desde pelo menos dois séculos, ensinou-nos a desejar a extensão das liberdades políticas, das ciências, das artes e das técnicas. Ensinou-nos a legitimar esse desejo porque esse progresso, dizia, devia emancipar a humanidade do despotismo, da ignorância, da barbárie e da miséria. A república é a humanidade cidadã. Esse progresso prossegue hoje, sob a designação mais vergonhosa de desenvolvimento. Mas tornou-se impossível legitimar o desenvolvimento através da promessa de uma emancipação da humanidade inteira. Essa promessa não foi cumprida. O perjúrio não foi devido ao esquecimento da promessa; é o próprio desenvolvimento que impede de a cumprir. O neo-analfabetismo, o empobrecimento dos povos do Sul e do Terceiro-Mundo, o desemprego, o despotismo da opinião e portanto dos preconceitos repercutidos pelos media, a lei de que é bom o que é "performativo"? isto não é devido à falta de desenvolvimento, mas ao desenvolvimento. É por isso que já não ousamos chamar-lhe progresso. (1993, p. 114-115)

Faço esses esclarecimentos preliminares para apontar o lugar de onde falo. Este é um trabalho que 
se filia a uma perspectiva que "questiona as bases racionalistas e humanistas sobre as quais a sociedade moderna estabelece a concepção de si mesma" (Usher \& Edwards, 1994, p. 83). O que se abandonam são algumas certezas e alguns ideais modernos: o centramento do sujeito - racional, autônomo, livre, estável, soberano, no controle de suas ações (ou capaz de chegar a ser tudo isso) -, a crença no modelo de racionalidade científica instaurado pelo Iluminismo, a idéia de que há um mundo cujo inevitável progresso se alcançará pela marcha perfectiva da História. O que as formulações pós-estruturalistas colocam em xeque é a moderna idéia de sistemas para explicar o mundo, brindando-nos com alguns lampejos do que se pode tomar como uma perspectiva "desancorada" de entendermos isso que tomamos como "real": uma perspectiva que se quer cética, desconfiada, problematizadora. Assim, tal perspectiva propõe a inquirição constante da verdade e das operações que a constituíram como tal, e, mais especialmente, dos grandes modelos explicativos da filosofia e da ciência modernas, desafiando-nos a lançar novos olhares sobre aquilo que todos pensavam conhecer (Veiga-Neto, 1995).

Utilizo-me dessas informações, ainda que sucintas, a fim de mostrar para que ponto focal as minhas investigações se movimentam. Elas assumem um registro diferente do usual e propõem outras formas de entender-se o fenômeno da infância e sua educação institucionalizada. Nelas, problematizo noções tradicionais como pedagogia, currículo, infância, e discuto como as perspectivas de significar tais conceitos e essa etapa da vida dos seres humanos estão de tal modo naturalizadas que deixam pouco espaço para que pensemos esses conceitos de outra forma e para que ponhamos em questão os processos que vieram a constituí-los nessa direção.

$\mathrm{O}$ mote central da pesquisa, que dá origem à temática mais restrita que abordo neste artigo, foi mostrar como o RCN assume o caráter de um dispositivo pedagógico ao pôr em marcha discursos - filosóficos, morais, "científicos"... -, ao instituir práticas, ao definir a organização do espaço, ao propor a distribuição do tempo, ao orientar decisões pedagó- gicas e administrativas que afetam, em minúcias, as vidas das crianças pequenas, no espaço institucional da educação infantil.

O estudo esteve interessado, portanto, em discutir as relações entre infância e poder. A sua perspectiva foi a de fazer aquilo que Foucault denominou uma analítica de poder. E recorro a Mitchell Dean (1999, p. 21), a fim não só de explicitar as operações que compõem uma analítica de poder ou de governamento, mas também, de certo modo, de configurar o escopo do estudo que realizei:

Uma analítica de um particular regime de práticas busca, no mínimo, identificar a emergência daquele regime, examinar as múltiplas fontes de elementos que o constituem e seguir os diversos processos e relações pelas quais estes elementos são reunidos em formas relativamente estáveis de organização e prática institucionais. Examina como este regime dá origem e depende de formas particulares de conhecimento e como, em conseqüiência disso, torna-se alvo de vários programas de reforma e mudança. Considera a dimensão técnica ou tecnológica deste regime e analisa suas técnicas, suas instrumentalidades e os mecanismos característicos através dos quais opera, tenta realizar as suas metas e através dos quais tem também uma multiplicidade de efeitos.

O que fiz, portanto, foi mostrar os modos de operar de um poder insidioso, onipresente, capilar - um poder modesto, desconfiado mas permanente -, cuja forma de expressão é uma maquinaria que se encarrega da regulação da infância - tanto uma racionalidade governamental ${ }^{4}$ quanto um conjunto de tecnologias que se apóiam num sistema de expertise, cujo objetivo é tornar pensável a vida das populações, neste caso a infantil, para nela intervir.

\footnotetext{
${ }^{4} \mathrm{Na}$ perspectiva foucaultiana, o adjetivo governamental não
} está associado necessariamente ao envolvimento ou à ação do Estado. O uso desta expressão - governamental - se faz para indicar que as práticas ou racionalidades (ou o que mais se queira adjetivar) estão implicadas com o governamento como "condução da conduta". 


\section{A centralidade dos discursos}

É preciso pegar as coisas para extrair delas as visibilidades. E a visibilidade de uma época é o regime de luz, e as cintilações, os reflexos, os clarões que se produzem no contato da luz com as coisas. Deleuze. 2000, p. 120

Feitas essas referências mais gerais ao escopo do meu estudo, é preciso começar a circunscrever e dar contornos mais definidos àquilo que vou tratar neste artigo. Sigo, portanto, detalhando mais alguns dos aspectos-chave dessa perspectiva "desancorada" que me serve de inspiração.

Quando defini o $\mathrm{RCN}^{5}$ como foco principal do meu estudo, tomei-o na qualidade de um discurso pedagógico que articula, no interior das instituições, jogos de poder e vontades de saber. Assim, o que estava em jogo era o caráter do RCN como um dispositivo, um conjunto de estratégias do qual o poder se vale para investir-se na e sobre a infância. O que era preciso tornar mais explícito eram as formas de operar dessas estratégias que atuam no campo pedagógico. Era necessário mostrar, utilizando como recurso o que Foucault chama de tecnologias disciplinares e tecnologias da experiência de si, como os modelos para conduzir a ação pedagógica propostos no documento têm por objetivo pôr em ação um conjunto de técnicas que não são da ordem da repressão ou do constrangimento, mas da produção e da estimulação da subjetividade. Ou que os sujeitos infantis auto-re-

${ }^{5}$ Ao longo da pesquisa, não me ative, no entanto, de modo exclusivo aos discursos propostos pelo RCN. No decorrer do trabalho empírico, fui matizando-os com outros discursos sobre a infância captados em outras fontes: os textos da revista Criança, editada pelo Ministério da Educação (MEC), e materiais provenientes da mídia e da mídia eletrônica estabelecem "os vínculos, os nexos, os liames entre um jogo de proposições e uma série de ações possíveis que têm por objetivo produzir crianças de um certo tipo" (Bujes, 2001, p. 106). flexivos e auto-regulados que este instrumento burocrático pretende formar, como diz Hunter (1996, p. 163), "são o resultado de uma iniciação incondicional nas disciplinas da consciência".

A perspectiva sobre a qual os meus estudos se apóiam afirma que os objetos do mundo social são construídos discursivamente, não apenas pelo uso da linguagem falada ou escrita, mas também por meio da utilização de sistemas de representação que nos permitem utilizar signos e símbolos para representar o que existe à nossa volta, seja um conceito, uma idéia ou imagem (Du Gay et al., 1997). A "virada lingüística” é responsável por esse modo de conceber a linguagem, mostrando o papel fundamental que esta desempenha na instituição dos sentidos que damos às coisas do mundo. Portanto, nessa perspectiva, os significados não estão dados para sempre, eles são sempre transitórios porque são constituídos historicamente. Os significados não correspondem a uma qualidade essencial do objeto que temos que desvelar; a essência das coisas nada mais é do que uma invenção humana, instituída nas trocas e negociações de sentido que estabelecemos intersubjetivamente. Desse modo, a linguagem não faz a mediação entre o que vemos e o pensamento, ela constitui o próprio pensamento. Assim, "quando alguém ou algo é descrito, explicado, em uma narrativa ou discurso, temos a linguagem produzindo uma 'realidade', instituindo algo como existente de tal ou qual forma" (Costa, 2000, p. 77). É com base nesses raciocínios que podemos dizer que não usamos a linguagem apenas para descrever e interpretar o mundo; as linguagens que utilizamos estão profundamente implicadas na instituição de práticas e na constituição de identidades sociais.

Tal forma de pensar a linguagem e seu papel instituidor de sentidos sobre isto que tomamos como o "real" nos leva a perceber que a "descoberta" do sujeito infantil na Modernidade - e a proliferação de discursos que se enunciam sobre ele - teve e tem efeitos muito concretos nas práticas destinadas à sua captura e educação. Os discursos sobre as crianças e a infância, ao se manifestarem sobre tais objetos, não estão aí para descrevê-los em sua inteireza (eles jamais 
conseguiriam fazer isso), mas para manifestar e traduzir [como disse Foucault, citado por Veiga-Neto, 1996] o querer fundamental daqueles que falam. (Bujes, 2002, p. 5)

É bem por isso que o regime de visibilidade a que foi (e continua sendo) submetida a infância, nos tempos modernos, esteve (e está) associado à intensificação da produção discursiva sobre esse novo objeto, fazendo com que os fenômenos relacionados com a população infantil passassem a ser descritos, ordenados, medidos, calculados, categorizados, tornando as crianças e a infância alvos de determinadas instituições e foco de tecnologias de poder.

Assim, a analítica de governamento da infância que produzi no meu estudo - Infância e maquinarias (Bujes, 2001) -, e da qual decorrem algumas das discussões que apresento neste artigo, teve por objetivo mostrar como as práticas discursivas instituídas pelo RCN têm como finalidade mobilizar um complexo de forças, de práticas, de saberes, constituindo um esforço organizado para a produção das subjetividades infantis.

\section{Tecnologias do eu e governamento da infância}

O propósito deste artigo é examinar como as chamadas tecnologias do eu operam quando tomam as crianças como seus objetos. O que nele enfatizo é como, no campo pedagógico, as proposições do RCN fazem funcionar as pedagogias comprometidas com o que Foucault chamou de práticas de si. A idéia é mostrar que a invenção do sujeito infantil como um sujeito autônomo, livre, transparentemente autoconsciente, visto como fonte de conhecimento e de ação moral e política (Peters, 2000) é uma tarefa sempre ameaçada, sempre inconclusa, que os ideais modernos necessitam reafirmar constantemente. É por esta razão que se constroem narrativas capazes de reafirmar tais características, tais comportamentos e sensibilidades e, pela mesma razão, constitui-se também "uma experiência tal que os indivíduos [são] levados a reconhecer-se como sujeitos" (Foucault, 1998, p. 10). Assim, o que pretendo pôr em evidên- cia é esse caráter inventado do sujeito infantil, vendo-o como produto de um processo muito complexo de definição, de interesses vindos de muitos lugares dispersos pela sociedade e apoiado numa produção convergente de saberes, proveniente de pontos variados do campo do saber. Este $e u$ capaz de um auto-escrutínio, que se sujeita a uma autoproblematização para encontrar a si mesmo, este sujeito que se volta intencionalmente para seu interior, que é visto com um locus de pensamento e de ação, é aqui concebido como uma invenção histórica.

Como discuti extensamente em Infância e maquinarias (Bujes, 2001), os sujeitos modernos, entre eles os infantis, foram sendo "montados" no interior de um conjunto de práticas discursivas: um complexo de narrativas sobre o eu que nossa cultura torna disponível e que os indivíduos utilizam para relatar os eventos de suas vidas, para atribuir a si mesmos uma identidade no interior de uma história particular e para dar significado à sua conduta e à dos outros (Rose, 1996, p. 175).

Esse processo de constituição do sujeito, ou de subjetivação,

\section{[...] é o nome que podemos dar ao efeito da composição e recomposição de forças, práticas e relações que lutam ou operam para tornar os seres humanos formas diversas de sujeitos, capazes de tomar a si mesmos como sujeitos de suas próprias práticas ou de práticas alheias que atuam so- bre eles. (idem, p. 171)}

Como argumentam vários autores com base no próprio Foucault (Rose, 1996; Larrosa, 1994), a experiência em que os sujeitos se reconhecem como tal é uma experiência de atribuição de sentido às próprias condutas e às alheias. A experiência de si, para Larrosa (1994, p. 43), produz-se quando o sujeito faz certas coisas consigo mesmo: "quando se observa, se decifra, se interpreta, se descreve, se julga, se narra, se domina". Isso faz com que uma série de recursos intelectuais, constantemente refinados, sejam mobilizados como mecanismos para constituir as relações do sujeito consigo mesmo: 
Dispositivos de "produção de sentido"- grades de visualização, vocabulários, normas e sistemas de julgamento - não são produzidos pela experiência; eles produzem a experiência. Essas técnicas intelectuais não nos chegam prontas, mas têm que ser inventadas, refinadas e estabilizadas, para serem disseminadas e implantadas, sob diferentes formas, em diferentes práticas - escolas, famílias, ruas, locais de trabalho, tribunais. Se utilizamos o termo "subjetivação" para designar todas essas práticas e esses processos heterogêneos por meio dos quais os seres humanos vêm a se relacionar consigo mesmos e com os outros como sujeitos de um certo tipo, então a subjetivação tem a sua própria história. E a história da subjetivação é mais prática, mais técnica e menos unificada do que supõem as análises sociológicas. (Rose, 1996, p. 25)

Assim, a experiência de si (Larrosa, 1994) depende de redes de comunicação em que se produzam e se contem histórias: está associada a esse processo de ouvir, de contar, de ler, de inventar e reinventar histórias, de participar ativamente da experiência cultural.

Para Rose (1996), os efeitos disso que é tomado como "interior psicológico" e o amplo espectro de outras capacidades e relações que nos formam se constituem pela conexão dos seres humanos com uma multiplicidade de outros objetos, práticas e forças. Nesse jogo de relações e de associações é que eles se constituem como sujeitos. Portanto:

[...] eles mesmos dão origem aos fenômenos através dos quais, em nosso tempo, os seres humanos vêem a si mesmos como possuindo um interior psicológico, como seres desejantes, sexuados, trabalhadores, pensantes, seres intencionados capazes de agir como sujeitos. Uma forma melhor de ver os sujeitos, [...], é como "agenciamentos" que metamorfoseiam ou mudam suas propriedades à medida que expandem suas conexões, que são nada mais nada menos que as conexões cambiantes nas quais eles estão associados. (idem, p. 172)

Assim, ao falar de um eu inventado, refiro-me a formas de autoconsciência e de autocompreensão que os seres humanos adquiriram ao longo de suas vidas e das quais lançam mão para poder viver. A invenção deste eu nada mais é do que um efeito de discursos que constituem tanto as relações de poder quanto a subjetividade. Discursos que definem o que pode ser dito e pensado; quem pode falar e quando isso deve ocorrer. Discursos que ordenam e combinam certas palavras e que, ao mesmo tempo, excluem tantas outras (Ball apud Usher \& Edwards, 1994).

Com base nas considerações precedentes, que enfatizam o caráter discursivo, histórico e contingente desse processo de constituição das subjetividades e da sua inescapável e inextricável vinculação aos jogos de poder, passo a examinar, neste texto, o modo como as tecnologias da subjetividade têm operado na constituição de sujeitos, utilizando para isto o produtivo corpo de conhecimentos que a perspectiva foucaultiana me oferece. O exame que faço do RCN proposto pelo MEC para a educação infantil tem também o propósito de mostrar que a experiência de si é ensinada às crianças como novos membros de uma cultura, e que isso não se dá de modo aleatório. Ao mesmo tempo em que as vivências nas creches e pré-escolas permitem às crianças construir uma experiência do mundo exterior, elas transmitem e constroem a experiência que as crianças têm de si mesmas como sujeitos (Larrosa, 1994). Será de experiências de tal tipo, identificáveis nas práticas e nos pressupostos presentes no RCN, que passarei a tratar a seguir.

\section{A tecnologia em ação: decifrar-se e transformar-se na experiência pedagógica}

A análise que faço, nesta seção, das experiências pedagógicas que visam constituir os sujeitos está baseada numa metodologia produzida por Larrosa (1994). Tal metodologia propõe-se a elaborar uma determinada forma de problematização das práticas pedagógicas que têm por finalidade a construção e a transformação da subjetividade.

Para o autor, a experiência que os sujeitos têm de si mesmos ocorre num processo histórico de fabricação em que se entrecruzam discursos que definem a verdade sobre o sujeito, práticas que regulam o seu comportamento e formas de subjetividade. 
A experiência de si, então, está associada àquelas práticas em que o sujeito faz coisas consigo mesmo. Larrosa (1994) identifica cinco dimensões da experiência de si: a ótica, a discursiva, a jurídica, a narrativa e a prática. Para este autor, tais dimensões - que funcionam de modo tal que se interpenetram - manifestam-se nas experiências que os seres humanos fazem consigo mesmos no interior de certos aparatos de subjetivação. Seriam as experiências, no interior das práticas pedagógicas, por exemplo, que construiriam e mediariam a relação do sujeito consigo mesmo, a experiência de si. Assim, no modelo teórico de inspiração foucaultiana que o autor propõe,

\section{[...] a experiência de si pode ser analisada como resultado do entrecruzamento, em um dispositivo pedagógico, de tec- nologias óticas de auto-reflexão, formas discursivas (basi- camente autonarrativas) de auto-expressão, mecanismos jurídicos de auto-avaliação e práticas de autocontrole e de autotransformação. (p. 38)}

Ao aplicar-se o seu modelo, o importante para o autor é que as experiências selecionadas para exame estejam dentro do espectro das chamadas práticas pedagógicas, "nas quais o mais importante não é que se aprenda algo exterior, um corpo de conhecimentos, mas que se elabore ou reelabore alguma forma de relação reflexiva do educando consigo mesmo" (Larrosa, 1994, p. 36). O que o autor pretende é mostrar que existe uma lógica geral nos dispositivos pedagógicos. As experiências em que o sujeito constrói a relação consigo mesmo estão sujeitas a uma "gramática” que possibilita múltiplas realizações.

É com base no modelo sucintamente descrito acima que passo a examinar aquelas experiências que, no RCN, considero emblemáticas dessa produção e mediação pedagógica da "experiência de si”, pelas quais as pessoas aprendem a ser pessoas dentro de um determinado repertório de possibilidades.

O ponto de partida desta seção é tomar estas duas ordens de preocupações - autodecifração e autotransformação - como modeladoras/moduladoras das práticas que se exercem sobre as crianças, sem no entan- to procurar demonstrar qual delas prevalece sobre a outra. As técnicas de si vão constituir as práticas que incitam os sujeitos tanto a decifrar-se quanto a transformar-se. Tanto a conhecerem a verdade sobre si mesmos quanto a agirem como sujeitos morais, buscando efetuar em si mesmos as transformações necessárias para viver melhor.

Foucault, ao trabalhar especificamente os modos como o sujeito se constitui como objeto para si mesmo, mostra-nos que esse processo em que o sujeito estabelece uma relação consigo mesmo é inseparável das tecnologias do eu, vistas como aquelas práticas

\footnotetext{
[...] que permitem aos indivíduos efetuar, por conta própria ou com a ajuda de outros, certo número de operações sobre seu corpo e sua alma, pensamentos, conduta, ou qualquer forma de ser, obtendo assim uma transformação de si mesmos com o fim de alcançar certo estado de felicidade, pureza, sabedoria ou imortalidade. (1995, p. 48)
}

O que faço neste texto, dando atenção ao detalhe, é examinar como o RCN está comprometido com certas políticas de identidade, com a fabricação de certos tipos de sujeitos.

\section{As operações de decifração}

Analiso aqui as dimensões fundamentais que, segundo o modelo proposto por Larrosa (1994), constituem os dispositivos pedagógicos nos quais se produz e se medeia a experiência de si. Tomando como referência as cinco dimensões propostas pelo autor as dimensões ótica, discursiva, jurídica, narrativa e prática -, delas vou valer-me para apontar como a experiência pedagógica, proposta às crianças e suas professoras, as faz viver uma experiência tal que as constitui como sujeitos morais: que se percebem, se conhecem, enfim, que se decifram e que, ao mesmo tempo, operam transformações no seu modo de ser, com base em um autojulgamento.

Ao recorrer às dimensões propostas, vou agrupar as voltadas para o autoconhecimento ou autode- 
cifração - dando atenção aos procedimentos em que os indivíduos elaboram as relações consigo mesmos e se vêem como objetos que podem ser conhecidos e aquelas que dizem respeito às operações que visam que o sujeito transforme o seu modo de ser - praticando-se para vir a constituir-se como um sujeito moral. Entendo, no entanto, que tais operações não sejam tão distintas em seus modos de operar. Elas agem em conjunto, de maneira potencializada e concomitante, no que estou apelando para uma violência didática ao, de certo modo, tentar vê-las como ações singulares.

\section{Ver-se}

Um dos propósitos mais salientes de qualquer experiência educativa, nos moldes nas quais as conhecemos presentemente, é fazer o indivíduo avançar no conhecimento de si mesmo. O RCN não foge a tais características:

Saber o que é estável e o que é circunstancial em sua pessoa, conhecer suas características e potencialidades e reconhecer seus limites é central para o desenvolvimento da identidade e para a conquista da autonomia. (Brasil, 1998,

v. 2, p. 11)

Quando formulamos a expressão "ver a nós mesmos" estamos pensando na possibilidade de voltarmo-nos para o nosso interior e dele extrairmos uma compreensão daquilo que somos, daquilo que queremos, a verdade sobre nós mesmos. A mente humana seria vista, segundo Larrosa (1994), como um olho que pode ver/conhecer as coisas. Assim, o autoconhecimento seria propiciado pela curiosa faculdade do olho da mente "de ver o próprio sujeito que vê" (Idem, p. 58). Esta metaforização ótica do autoconhecimento ${ }^{6}$ pode, segundo Larrosa, ser tomada em

${ }^{6}$ Esta concepção está associada a toda uma reconstrução renascentista do sentido da visão que afeta radicalmente a concepção de tempo e de espaço no mundo ocidental. Neste sentido, dois sentidos. No primeiro, o olho da mente pode ver "por reflexão", isto é, exteriorizar, como num jogo de espelhos, o que o sujeito vê de si mesmo. O autoconhecimento seria "algo análogo à percepção que a pessoa tem da sua própria imagem na medida em que pode receber a luz que foi lançada através do espelho" (idem, p. 59). Desse modo, para autoconhecer-se seria necessária uma certa exteriorização e objetivação da própria imagem. Como se, ao verse convertida em objeto, a pessoa passasse a ver a si mesma. Tal perspectiva pode ser melhor entendida na forma com que o RCN significa a questão da consciência do próprio corpo:

No plano da consciência corporal, nessa idade a criança começa a reconhecer a imagem de seu corpo [...] por meio das interações sociais que estabelece e das brincadeiras que faz diante do espelho. Nessas situações, ela aprende a reconhecer características físicas que integram a sua pessoa, o que é fundamental para a construção de sua identidade. (Brasil, 1998, v. 3, p. 23)

A maneira como cada um vê a si próprio depende também do modo como é visto pelos outros. $\mathrm{O}$ modo como os traços particulares de cada criança são recebidos pelo professor, e pelo grupo em que se insere, tem um grande impacto na formação de sua personalidade e de sua autoestima, já que sua identidade está em construção. (Brasil, 1998, v. 2, p. 13)

A aquisição da consciência dos limites do próprio corpo é um aspecto importante do processo de diferenciação do eu e do outro e da construção da identidade. (Brasil, 1998 , v. 2, p. 25)

é esclarecedora a formulação de Harvey (1992, p. 223) para quem: "O perspectivismo concebe o mundo a partir do 'olho que vê' do indivíduo. Ele acentua a ciência da ótica e a capacidade das pessoas de representarem o que vêem como uma coisa de certo modo 'verdadeira', em comparação com verdades sobrepostas da mitologia ou da religião. A ligação entre o individualismo e o perspectivismo é relevante; ela forneceu o fundamento material eficaz aos princípios cartesianos de racionalidade que foram integrados ao projeto do Iluminismo". 
O outro sentido deste "ver-se a si mesmo" exclui o movimento reflexivo da luz; "uma espécie de percepção interna [...] se produziria ao voltar o olhar, este olhar que normalmente está dirigido às coisas exteriores, para si mesmo" (Larrosa, 1994, p. 59). A observação, nesse caso, reproduziria o modelo sujeito-objeto, mas este objeto não estaria refletido fora do sujeito, e sim, dentro dele mesmo. As coisas que seriam vistas fariam parte do domínio privado daquele que vê.

O que Larrosa (1994) nos mostra é que o imperativo reflexivo, esta exigência de que devamos conhecer a nós mesmos, carrega este duplo sentido descrito acima: "há algo de mim que conhece e algo que é conhecido" (p. 60). Assim, a busca de uma imagem o menos distorcida possível, um ideal de transparência, pode ser entendido como um poderoso ideal pedagógico.

Foucault explora de forma bastante consistente, em sua obra, a questão da visibilidade. ${ }^{7}$ As instituições educacionais, entre elas as destinadas às crianças pequenas, são máquinas de fazer ver. Os dispositivos para tornar visíveis as crianças estão propostos ao longo do $\mathrm{RCN}$ e, ao colocarem o máximo de atenção na criança, tornam praticamente invisíveis as relações de poder a que ela está sujeita ou as formas de dominação que se aplicam sobre ela.

Ao comentar como a questão do olhar é significada pela perspectiva pós-moderna e ao creditar ao Iluminismo uma extrema desconfiança em relação à possibilidade de que o que é visto o seja com clareza e fidelidade ao objeto, Veiga-Neto (1996, p. 27) vai afirmar que:

Se para o Iluminismo é preciso tomar cuidado com as impressões imediatas, para as perspectivas pós-modernas

${ }^{7}$ Em vários de seus escritos, Foucault desenvolve o tema da visibilidade. Este é um tema recorrente que está em As palavras e as coisas, na História da loucura, em $O$ nascimento da clínica, em Vigiar e punir, na História da sexualidade e abrange desde a análise da representação clássica até a arquitetura do panóptico e o dispositivo da confissão. O que Foucault faz, em todos esses escritos, é uma análise de como se constituem historicamente os dispositivos ou as máquinas de fazer ver. qualquer impressão é, ao mesmo tempo que impressão, também uma conformação do mundo. Isso significa que as imagens que o mundo, principalmente social, nos apresenta, a rigor, ele não nos apresenta isentamente, isso é, é o olhar que botamos sobre as coisas que, de certa maneira, as constitui. São os olhares que colocamos sobre as coisas que criam os problemas do mundo. (grifo meu)

Assim, o fato de o indivíduo "ver-se" está balizado por formas óticas preexistentes na cultura, o que coloca em questão a possibilidade de um sujeito cuja consciência, cujas formas de pensar e de sentir sejam transparentes, um sujeito no controle de tais processos e, portanto, no controle de si mesmo, imune a influências vindas de fora ou do seu próprio interior.

Como aponta Larrosa (1994), ao formular a questão da visibilidade Michel Foucault vai mostrar-nos que tanto o que é visível como o olho que vê fazem parte de um mesmo movimento. Portanto,

\section{[...] um regime de visibilidade composto por um conjunto específico de máquinas óticas abre o objeto ao olhar e abre, ao mesmo tempo, o olho que observa. Por isso o sujeito é uma função da visibilidade, dos dispositivos que o fazem ver e orientam o seu olhar. (p. 61)}

$\mathrm{O}$ arsenal pedagógico é bastante rico em instrumentos que têm por finalidade afinar estas operações para tornar visíveis as crianças e seus processos: a auto-observação, a auto-avaliação, as fichas de observação, os registros, os exames, as produções escritas, os desenhos, as rodas de conversa... Por tais mecanismos pretende-se não apenas que a criança se tome como objeto para si mesma, se autoconheça, mas, ao mesmo tempo ou alternativamente, que ela se exponha ao escrutínio alheio. A criança que era vigiada nas práticas disciplinares, agora agrega a esta experiência o exercício da autovigilância. Como diz Corazza (1998, p. 540),

O indivíduo interior é diagramatizado, de um modo que a subjetivação do homem livre se transforma em sujeição: 1) por um lado, é a submissão ao outro pelo controle e pela dependência, com todos os procedimentos de indivi- 
dualização e de modulação que o poder instaura; 2) por outro, é o apego de cada um à sua própria identidade, mediante a consciência e o conhecimento de si, com todas as técnicas das ciências morais e humanas que formam o saber do sujeito.

Creio que, em relação às tecnologias do eu presentes nas proposições do RCN, interessa tomarmos como uma referência exemplar o dispositivo da confissão. Ao analisar as transformações que ocorrem nos mecanismos de subjetivação na modernidade, Foucault vai prestar uma especial atenção aos rituais em que o sujeito é posto em confronto consigo próprio ao mesmo tempo em que se expõe àquele que o observa:

A confissão é um ritual de discurso onde o sujeito que fala coincide com o sujeito do enunciado: é, também, um ritual que se desenrola numa relação de poder, pois não se confessa sem a presença ao menos virtual de um parceiro, que não é simplesmente o interlocutor, mas a instância que requer a confissão, impõe-na, avalia-a e intervém para julgar, punir, perdoar, consolar, reconciliar; [...] um ritual onde a enunciação em si, independentemente de suas consequiências externas, produz em quem a articula modificações intrínsecas: inocenta-o, resgata-o, purifica-o, livra-o de suas faltas, libera-o, promete-lhe a salvação. (1997, p. 61)

Os dispositivos que fazem funcionar a experiência de si também incluem mecanismos que levam a criança a aprender a usar as regras para ver-se de modo correto. Desse modo, essa experiência de se autoconhecer é balizada por um repertório e por um "sentido de propriedade" que vai adequando não apenas o que há para ver em si mesmo, mas o que é preciso reformular para ajustar-se ao que é esperado. Assim, o RCN preconiza:

As capacidades de interação [...] são desenvolvidas quando as crianças podem ficar sozinhas, quando elaboram suas descobertas e sentimentos e constroem um sentido de propriedade para as ações e pensamentos já compartilhados com outras crianças e com adultos. [...] Nas situações de troca, podem desenvolver os conhecimentos e recursos de que dispõem, confrontando-os e reformulando-os. (Bra-

sil, 1998, v. 1, p. 31)

\section{Expressar-se}

As práticas em que cada um de nós se decifra possuem também uma dimensão discursiva. Tal dimensão da experiência de si, presente no dispositivo pedagógico, está constituída por atividades em que as crianças devem basicamente falar e escrever. $\mathrm{Na}$ área da educação infantil, entretanto, a isso se poderia agregar o brincar, o desenhar, o dramatizar... A dimensão discursiva se expressaria nas diferentes formas de linguagem que as crianças utilizam. Este enunciado, que diz respeito ao movimento, é bastante representativo desta concepção ampliada das linguagens pelas quais a criança se expressa:

As maneiras de andar, correr, arremessar, saltar resultam das interações sociais e da relação dos homens com o meio; são movimentos cujos significados têm sido construídos em função das diferentes necessidades, interesses, possibilidades corporais humanas, presentes nas diferentes culturas, em diversas épocas da história. [...] Ao brincar, jogar, imitar, criar ritmos e movimentos, as crianças também se apropriam do repertório da cultura corporal na qual estão inseridas. (Brasil, 1998, v. 3, p. 15)

Na dimensão discursiva estabelece-se e constitui-se aquilo que o sujeito pode e deve dizer acerca de si mesmo (Larrosa, 1994). Nessa perspectiva, expressar é fazer vir à tona algo que já está no interior da pessoa: "A linguagem serve para apresentar aos outros o que já se faz presente para a própria pessoa. A linguagem apresenta de uma forma repetida, representa, duplica em um meio exterior o que já estava apresentado, tornado visível no interior" (idem, p. 63). Tal é o sentido que o RCN dá a uma série de atividades enumeradas a seguir:

Cabe ao professor propiciar situações de conversa, brincadeiras ou de aprendizagens orientadas que garantam a troca entre as crianças, de forma a que possam comuni- 
car-se e expressar-se, demonstrando seus modos de agir, de pensar e de sentir, em um ambiente acolhedor e que propicie a confiança e a auto-estima. (Brasil, 1998, v. 1, p. 31)

A primeira função do ato motor está ligada à expressão, permitindo que desejos, estados íntimos e necessidades se manifestem. (Brasil, 1998, v. 3, p. 18)

Enquanto desenham ou criam objetos [as crianças] também brincam de faz-de-conta e verbalizam narrativas que exprimem suas capacidades imaginativas, ampliando sua forma de sentir e de pensar sobre o mundo em que estão inseridas. (Brasil, 1998, v. 3, p. 93)

Em sua análise das dimensões da experiência de si, Larrosa (1994) apresenta dois modos de entender a linguagem: um referencial e outro expressivo. No primeiro, o de referência, a linguagem é vista como cópia da realidade, por intermédio de uma representação perfeita, "na qual a linguagem é simplesmente um meio representacional transparente para descrever a natureza do mundo, fazendo-o presente, sem se interpor/interferir entre o sujeito que observa e o mundo", como afirmam Usher e Edwards (1994, p. 57). No segundo, a linguagem exterioriza o que se encontra no interior do sujeito. Nas atividades da educação escolar na Espanha, como nos diz Larrosa (1994), a metáfora da exteriorização é a dominante. Também no RCN, quando as crianças dançam, cantam, pintam, dramatizam, falam etc. (atividades classificadas como de expressão), elas estariam mostrando a si mesmas, apresentando aquilo que elas mesmas são, conforme se pode inferir do fragmento a seguir:

A articulação entre as sensações corporais e as marcas gráficas, bem como o registro gráfico que surgir daí, fornecerá às crianças um maior conhecimento de si mesmas e poderá contribuir para as atividades de representação da própria imagem, dos sentimentos e de suas experiências corporais. (Brasil, 1998, v. 3, p. 98)

Mas, mesmo quando as crianças utilizam-se da fala ou de outra forma de linguagem para expressar estados interiores, ideações ou avaliações, mesmo quando as crianças usam uma linguagem categorizada como referencial, diz Larrosa (1994), esta idéia da linguagem como expressão é dominante. O que está associado a isto é uma nítida separação entre um âmbito interior e outro exterior, tendo a linguagem como mediadora entre estados internos de consciência e o mundo exterior.

Daí resulta toda uma idéia do falante e do discurso expressivo: as pessoas, ao produzirem signos, atingem maior ou menor competência expressiva, maior ou menor sinceridade expressiva, maior ou menor espontaneidade expressiva. Poder-se-ia, então, pensar num discurso prévio, ao mesmo tempo origem e referência, e, especialmente para o que nos interessa, "poderia haver, idealmente, uma competência plena, uma sinceridade absoluta e uma espontaneidade livre. [...] Todo um ideal, facilmente pedagogizável, da transparência comunicativa" (Larrosa, 1994, p. 65).

Para Foucault, há uma estreita relação entre o visível e o dizível. A formas legítimas de olhar correspondem formas legítimas de dizer. Mas não se pode dizer qualquer coisa em qualquer época. Tanto o que se vê como o que se diz dependem de condições históricas de possibilidade. É interessante, nesse sentido, mostrar como o RCN enfatiza que as oportunidades de interação, as trocas, as oportunidades de convívio em uma multiplicidade de situações, são essenciais à constituição subjetiva das crianças:

As crianças se desenvolvem em situações de interação social, nas quais conflitos e negociação de sentimentos, idéias e soluções são elementos indispensáveis. (Brasil, 1998, v. 1, p. 31)

O âmbito social oferece, portanto, ocasiões únicas para elaborar estratégias de pensamento e de ação, possibilitando a ampliação das hipóteses infantis. Pode-se estabelecer, nesse processo, uma rede de reflexão e construção de conhecimentos na qual tanto os parceiros mais experientes quanto os menos experientes têm seu papel na interpretação e ensaio de soluções. (Brasil, 1998, v. 1, p. 31-32)

Argumento que este discurso da interação é relativamente recente no campo da pedagogia infantil e corresponde a um predomínio das teorias construtivistas 
como referencial orientador para as práticas educativas voltadas a crianças pequenas. Também são relativamente recentes as proposições que tratam das relações de gênero e as colocam como objetos que compõem os enunciados que tratam da educação infantil:

Além do modelo familiar, as crianças podem constatar, por exemplo, que nas novelas ou desenhos veiculados pela televisão homem e mulher são representados conforme visões presentes na sociedade. Estas visões podem influenciar a sua percepção quanto aos papéis desempenhados pelos sujeitos dos diferentes gêneros. (Brasil, 1998, v. 2, p. 20)

As crianças vão gradualmente percebendo-se e percebendo os outros como diferentes, permitindo que possam acionar seus próprios recursos, o que representa uma condição essencial para o desenvolvimento da autonomia. (Brasil, 1998, v. 2, p. 14)

A presença de tais temáticas no RCN vem corroborar a idéia de que novos objetos são incorporados ao discurso pedagógico e de que este não é estável nem estanque. A inclusão do tema das relações de gênero, bem como o das diferenças, mostra que os vocabulários utilizados para pensar as crianças, nas instituições, são históricos, móveis, contingentes. Guardam uma relação estreita com a candente discussão acerca das identidades, que se estende, desde há mais tempo, por este início de milênio. Mas é preciso não esquecer que

As estratégias políticas motivadas pelos ideais da identidade estão, sem dúvida, imbuídas, com igual freqüência, tanto pelos valores nobres do humanismo e de seu compromisso com a liberdade individual quanto por uma vontade de dominar ou purificar em nome da identidade. (Rose, 1996, p. 39)

Na concepção foucaultiana, não cabe a distinção entre diferentes tipos de discurso. Para o filósofo, o discurso é um mecanismo autônomo funcionando no interior de um dispositivo. Assim, não caberiam as distinções feitas nas páginas precedentes entre um discurso representativo e outro expressivo. Também não é o sujeito a origem do discurso. "O discurso tem seu pró- prio modo de existência, sua própria lógica, suas próprias regras, suas próprias determinações" (Larrosa, 1994, p. 66). Não existe, a rigor, um sujeito do discurso, mas posições discursivas que, ao mesmo tempo em que atribuem ao sujeito um lugar discursivo, constituem-no, num mesmo movimento. Também não cabe, nesta perspectiva, examinar se um discurso é verdadeiro ou falso, mas sob que condições ele se constituiu como tal. O discurso é também inseparável dos dispositivos materiais nos quais se produz. As práticas sociais - a elaboração do RCN, as creches e pré-escolas etc. - são tanto "máquinas óticas que produzem ao mesmo tempo o sujeito que vê e as coisas visíveis [como] máquinas enunciativas que produzem [também simultaneamente] significantes e significados" (p. 67).

$\mathrm{Na}$ perspectiva foucaultiana, palavra e imagem não se fundem. Veiga-Neto (1996, p. 30), na análise que faz da linguagem, nos diz que:

A linguagem não faz a mediação entre o que vemos e o nosso pensamento, mas ela constitui o próprio pensamento e, assim, precede o que pensamos ver no mundo. Para Foucault, são os elementos visíveis - formações não-discursivas - e os elementos enunciáveis - formações discursivas - que farão do mundo isto que ele parece ser para nós.

[...] Todos os entendimentos que temos sobre o mundo [...] se dão em combinações flutuantes entre olhares e enunciados, entre visão e palavra, entre formações não-discursivas e formações discursivas.

Assim, dispositivos pedagógicos como o RCN implicam visibilidades e enunciados. Neles, o discurso da pedagogia constitui, ao mesmo tempo, uma verdade sobre o sujeito e um conjunto de técnicas materiais, de jogos práticos para controlar a produção/ autoprodução de subjetividades assujeitadas de professoras $^{8}$ e das crianças.

${ }^{8}$ Fiz a opção por utilizar a palavra professoras, no feminino, em razão da representatividade numérica das mulheres como docentes, nessa etapa da educação básica. Isso não ocorre apenas neste texto, mas em todos os que tenho escrito sobre a educação infantil. 
O argumento a enfatizar é que as atividades propostas pelo RCN não apenas favorecem às crianças para que elas aprendam a expressar sentimentos, desejos, necessidades, como o documento pretende. $\mathrm{O}$ que de fato ocorre é muito mais do que isto, ou diferente disto: ao lidar com as propostas ali presentes, crianças e professoras aprendem que aquele é um discurso legítimo, que ele tem regras que precisam ser aprendidas e praticadas. Assim, o que realmente aprendem é uma gramática para se auto-expressarem, e um vocabulário apropriado para fazê-lo. Nessas experiências, as crianças tornam-se sujeitos que falam de si mesmos de uma certa maneira. Nessas práticas em que são instados a se descrever e se redescrever, não apenas se constroem como pessoas, se transformam segundo direções esperadas.

\section{Narrar-se}

Para Larrosa (1994), a dimensão narrativa é essencial ao processo de construção da experiência de si, pois é nessa experiência narrativa que a pessoa pode ver a si mesma, pode nomear os seus traços, pode definir os limites e os contornos de sua identidade, pode distinguir-se das demais:

A leitura de histórias é um momento em que a criança pode conhecer a forma de viver, pensar, agir e o universo de valores, costumes e comportamentos de outras culturas situadas em outros tempos e lugares que não o seu. (Brasil, 1998, v. 3, p. 143)

A dimensão narrativa compreende especialmente os processos que têm a ver com a ativação da memória, com a recordação, com o armazenamento. Aquilo que somos depende, em grande parte, das histórias a que estamos ligados temporalmente. Contar uma história é enumerar, ordenar os rastros que conservam o que se viu. É, de certa forma, prestar contas daquilo que ocorreu:

Uma das formas de ampliar o universo discursivo das crianças é propiciar que conversem bastante, em situações organizadas para tal fim, como na roda de conversa ou em brincadeiras de faz-de-conta. [...] A roda de conversa é o momento privilegiado de diálogo e intercâmbio de idéias. Por meio desse exercício cotidiano as crianças podem ampliar suas capacidades comunicativas, como a fluência para falar, perguntar, expor suas idéias, dúvidas e descobertas, ampliar seu vocabulário e aprender a valorizar o grupo como instância de troca e aprendizagem. (Brasil, 1998, v. 3, p. 138)

$\mathrm{O}$ fragmento anterior mostra-nos claramente que a constituição da experiência de si, como uma experiência narrativa, depende basicamente desta imersão dos sujeitos humanos em tramas dialogais entre narrativas, entre textos. Ao participar de práticas discursivas de caráter narrativo, as crianças não só modificam o vocabulário que utilizam para se autodescrever, como articulam os modos de narrar-se, de contar as suas histórias de vida. Nesse processo, o indivíduo constrói um sentido de quem ele é para si mesmo que é análogo à construção de um personagem numa trama narrativa: "A compreensão da própria vida como uma história que se desdobra, assim como a compreensão da própria pessoa como o personagem central da história, é algo que se produz nesses constantes exercícios de narração e autonarração nos quais estamos implicados cotidianamente" (Larrosa, 1994, p. 69).

A narração, nas experiências de si, é primordialmente autonarração, uma experiência de reconstituição temporal dos "fatos". Nela, o narrador, ao perceber a sua permanência no tempo, constrói sua temporalidade e amplia a consciência de sua inscrição no registro temporal. É na modernidade que se adensa, segundo Domingues (1996), essa consciência da ação implacável do tempo, representada pela corruptibilidade da natureza, pela fragilidade da existência, pela precariedade das instituições sociais. Resulta disso que os homens querem anular o efêmero, querem colocar-se ao abrigo da ação corrosiva do tempo. O que o domínio cognitivo sobre o tempo vai fazer é valer-se desse processo de narração para "amarrar" uma identidade congelada no tempo. Para evadir-se ao terror à finitude, é preciso instalar a eternidade com seus sistemas de permanência no tempo e no mundo: 
[...] são as instituições sociais, as tradições culturais e históricas, as formas de organização da memória coletiva etc., que, como os artificialia, são na modernidade potenciados numa escala jamais vista, ainda que acompanhadas da experiência da anomia, da quebra de identidade e do esfacelamento dessas mesmas entidades. (Domingues, 1996, p. 44)

A estes sistemas de permanência, Domingues (1996) associa um conjunto de formas de evasão temporal, as utopias, as ideologias milenaristas, a ciência e a filosofia, a técnica e a literatura. A experiência de dar-se temporalmente uma identidade, construindo-a narrativamente, serve para afastar a efemeridade e controlar o tempo. Desse modo, pode entender-se como a experiência de articulação temporal organiza-se e reforça-se narrativamente.

A história de vida é uma excelente forma de coleta de dados, por meio da reconstrução da trajetória de uma pessoa possibilita o acesso às informações sobre a comunidade, à vida em tempos passados, ou ainda sobre as transformações que a paisagem local já sofreu. (Brasil, 1998, v. 3, p. 196)

É importante que a criança aprenda a "ler" [...] objetos e imagens. Objetos antigos que pertencem às famílias, exposições de museus, vídeos, filmes, programas de televisão são poderosos recursos para se analisar como viveram as pessoas de outras épocas e grupos sociais. (Brasil, 1998, v. 3, p. 197)

Esses recursos de que a prática pedagógica proposta pelo RCN se vale, as histórias de vida, os objetos, as imagens, os filmes etc. servem de suportes para que as crianças construam as próprias narrativas a respeito de si mesmas. Quando elas narram o que lhes acontece, elas dão-se essa identidade no tempo. Como Rose (1997, p. 240) analisa em sua genealogia dos processos de subjetivação e de sua relação com o campo $p s i,{ }^{9}$ isto é produzido como efeito de tecnologias espe-

${ }^{9}$ Utilizo, neste texto, as expressões área psi ou campo psi para designar o conjunto de disciplinas - psicologia, psiquiatria, psicanálise... - e alguns campos de aplicação (ou práticas) a elas cíficas que representam, como vim argumentando ao longo deste artigo, nada mais nada menos que operações que implicam manifestos interesses de regulação:

A memória que temos de nós mesmos como um sujeito com um caráter singular, com uma biografia individual que tem raízes numa história familiar, é produzida e reunida com o auxílio de álbuns de fotografia da família, cartões de aniversário, retratos, boletins escolares, o curriculum vitae e uma série completa de outros documentos que atestam realizações práticas (accomplishments). A área psi é importante neste caso, não apenas porque ela fornece as linguagens nas quais estes artefatos são escritos ou por meio dos quais são lidos, mas também porque inventou uma série de tecnologias da memória que reativam o passado no presente como um conjunto de sentimentos e necessidades, emoções experimentadas ou reprimidas, ataques/ choques à auto-estima ou contribuições para a estabilidade da personalidade.

As implicações do que propõem Larrosa (1994), Rose (1996, 1997), Veiga-Neto (1996), Usher e Edwards (1994) e Domingues (1996) são bastante claras: o eu não se constitui de forma não-mediada, ele é produzido em contextos de narração e de autonarração. As narrativas preexistem ao sujeito e são elas que lhe permitem organizar e construir uma forma de experiência e dar-lhe significado. Daí porque a experiência de si acaba por envolver uma série de estratégias, como as propostas neste enunciado presente no RCN:

Boas perguntas, questionamentos interessantes, dúvidas que mobilizem o processo de indagação acerca dos elementos, objetos e fatos são imprescindíveis para o trabalho com o eixo Natureza e Sociedade. As boas perguntas, além de promoverem o interesse da criança, possibilitam que se conheça o que pensam e sabem sobre o assunto. É importan-

associadas - psicopedagogia, psicodiagnóstico... - que, desde o século XIX, têm estado envolvidas com a compreensão do funcionamento da "alma humana", "porque elas fizeram surgir uma variedade de novos modos nos quais os seres humanos passaram a entender a si mesmos e a fazer coisas com eles mesmos" (Rose, 1996, p. 2). 
te que as perguntas ou problematizações formuladas pelo professor permitam às crianças relacionar o que já sabem ou dominam com o novo conhecimento. Esse tipo de questionamento pode estar baseado em aspectos práticos do dia-adia da criança, relacionados ao modo de vida de seu grupo social (seus hábitos alimentares, sua forma de se vestir, o trabalho e as profissões que seus familiares realizam (sic), por exemplo); ou ainda ser realizado a partir de fotografias, notícias de jornais, histórias [...]. (Brasil, 1998, v. 3, p. 195)

O sujeito, na perspectiva cartesiana, não apenas conhece, ele sabe que conhece. Para Descartes, o domínio da razão e a autoconsciência são a garantia para a aquisição do conhecimento. $\mathrm{O}$ mundo, assim como a autoconsciência, são transparentes. Do mesmo modo, o sujeito pode autoconhecer-se por meio de uma reflexão não mediada, podendo, nesta perspectiva, apresentar-se a si mesmo (Usher \& Edwards, 1994).

Ao fazer a crítica da perspectiva acima, que a meu ver é aquela que orienta o que se toma por autoconhecimento no Referencial, pretendo ter mostrado que o processo pelo qual as crianças se tornam crescentemente autoconscientes não é um processo de autodescoberta, mas de auto-invenção. Auto-invenção esta que se constrói em certas experiências e é balizada por um conjunto finito de possibilidades.

Como vim enfatizando recorrentemente neste texto, as práticas que constituem a experiência de si, a exemplo de outras práticas que descrevi e analisei, estão atravessadas pela questão do significado e por relações de poder. Como vimos pelas formulações do RCN que destaquei ao longo desta seção, os seres humanos, ao construírem narrativamente a sua autoconsciência, o fazem no interior de um conjunto de operações discursivas que não estão isentas de violência. Assim, as práticas discursivas nas quais se produzem os sujeitos, no dispositivo pedagógico representado pelo RCN, não são autônomas. Elas correspondem a uma política de constituição das crianças e das professoras, cuja pretensão é produzir formas muito específicas de sujeitos.

Portanto, quando as crianças são vistas no RCN como autônomas, capazes de fazer suas escolhas li- vremente, empreendedoras, temos que convir que estas formas discursivas não são uma novidade para nós, nem se encontram dissociadas do modo como as crianças são concebidas/apresentadas em outros locais culturais. Tais concepções "estão incorporadas na própria linguagem que utilizamos para tornar as pessoas 'pensáveis' e em nossos ideais sobre a realização humana" (Rose, 1996, p. 151). Estas formas de pensar as características e os destinos dos indivíduos fazem parte de estratégias de governamento, baseadas em sistemas de expertise. São formas de concebê-las que engendram, num mesmo movimento, formas práticas de constituí-las. Entretanto, este é um empreendimento nunca alcançado plenamente, nunca finalizado. Ele não é de todo bem-sucedido, porque são tantas as determinações que se cruzam nesse processo que as tentativas para fazê-lo funcionar são sempre parcialmente frustradas. É por tal razão que as racionalidades de governamento põem em ação, constantemente, um amplo espectro de mecanismos e de programas que pretendem tanto modelar os eventos em domínios como o trabalho, o mercado, a família, a escola, quanto produzir valores considerados importantes na esfera pública como prosperidade, eficiência, saúde, bemestar, educação.

\section{O perando transformações}

A moral dá o tom a esta última seção, em que trato das práticas e dos saberes envolvidos na invenção do humano e de sua estreita relação com o dispositivo de governamento representado pelo RCN. Começo com duas formulações presentes no texto do RCN:

[Pela brincadeira, as crianças] tornam-se autoras de seus papéis, escolhendo, elaborando e colocando em prática suas fantasias e conhecimentos, sem a intervenção direta do adulto, podendo pensar e solucionar problemas de forma livre das pressões situacionais da realidade. (Brasil, 1998, v. 3, p. 23)

Por meio da repetição de determinadas ações imaginadas que se baseiam nas polaridades presença/ausência, bom/mau, prazer/desprazer, passividade/atividade, dentro/ 
fora, grande/pequeno, feio/bonito etc., as crianças também podem internalizar e elaborar suas emoções e sentimentos, desenvolvendo um sentido próprio de moral e justiça. (Brasil, 1998, v. 3, p. 23)

Do que se trata efetivamente nestes trechos é de crianças que fazem escolhas, elaboram modos de pensar, de sentir, de agir para construírem-se a si mesmas e transformarem-se num sentido moral. É a práticas de subjetivação que se referem tais enunciados, a modos como os sujeitos, que não existem como uma entidade portadora de uma essência perene, fundam-se e refundam-se a cada instante na história (Foucault, 1996).

É preciso advertir, no entanto, que nessa perspectiva existem distinções entre o domínio da moral, estritamente falando, e as práticas éticas, como explica Rose (1996, p. 30):

[...] os sistemas morais são, em geral, sistemas universais de obrigação e interdição - "não deves fazer isso" ou "não deves fazer aquilo" - e são, muito freqüentemente, articulados em relação a algum código relativamente formalizado. A ética, por outro lado, refere-se ao domínio de tipos específicos de conselho prático sobre como a pessoa deve se preocupar consigo mesma, fazer de si própria o objeto de solicitude e atenção, conduzir a si própria nos vários aspectos de sua existência cotidiana.

Uso as próprias formulações de Foucault no "Uso dos prazeres" para dar mais clareza às distinções que se impõe fazer neste texto. Ao formular o que entende por ações morais num sentido amplo, ele nos diz que:

Para ser dita "moral" uma ação não deve se reduzir a um ato ou a uma série de atos conformes a uma regra, lei ou valor. É verdade que toda ação moral comporta uma relação ao real em que se efetua, e uma relação ao código a que se refere; mas ela implica também uma certa relação a si; essa relação não é simplesmente consciência de si, mas constituição de si enquanto sujeito moral, na qual o indivíduo circunscreve a parte dele mesmo que constitui o objeto dessa prática moral, define sua posição em relação ao preceito que respeita, estabelece para si um certo modo de ser que valerá como realização moral dele mesmo; e, para tal, age sobre si mesmo, procura conhecer-se, controla-se, põese à prova, aperfeiçoa-se, transforma-se. (1998, p. 28)

Assim, o sujeito moral tanto pode estar submetido ao sistema de códigos e às regras de comportamento, quanto a formas de subjetivação e a práticas de si nas quais se dá ênfase "às formas de relação consigo, aos procedimentos e às técnicas pelas quais são elaboradas, aos exercícios pelos quais o próprio sujeito se dá como objeto a conhecer, e às práticas que permitem transformar seu próprio modo de ser" (Idem, p. 30). Estas últimas seriam as morais orientadas para a ética, voltadas para uma estética da existência - em que o sujeito pode fazer de sua vida uma obra de arte.

Ao entendermos a dimensão ética de um modo "prático" - como modos de avaliar e agir sobre si que foram desenvolvidos em diferentes épocas históricas podemos entender por que, nas diversas formações sociais, os temas que compõem as formulações morais não têm o mesmo valor ou significado (Fonseca, 1995).

No amplo domínio da moralidade, portanto, existem diferenças marcadas entre um campo mais estrito da moral - com seus códigos e os comportamentos das pessoas em relação a eles - e um campo da ética - com as relações que a pessoa estabelece consigo mesma. Os códigos morais oferecem preceitos que determinam o que pode ou não ser feito, as interdições, os atos proibidos - e, por extensão, os permitidos - enfim, a gradação, numa escala entre bom e mau, dos atos praticados. No domínio da ética, o que importa é o tipo de relação consigo próprio, que Foucault grifa como rapport a soi. ${ }^{10}$ Esta relação faz com que o indivíduo se constitua como sujeito moral de suas próprias ações.

Procurei mostrar até aqui como funcionam os mecanismos óticos e narrativos da experiência de si,

${ }^{10}$ Michel Foucault mostra-nos que, com o recurso às chamadas "tecnologias do eu", o indivíduo tanto estabelece relações com os outros (rapports à autrui) quanto relações consigo mesmo (rapports a soi). 
como eles agem para regular a vida individual e social. O arsenal foucaultiano vai apontar, no entanto, para o fato de que tais mecanismos, produtores de atos reflexivos de auto-observação, de auto-expressão e de autonarração, "seriam também inseparáveis dos dispositivos que tornam os indivíduos capazes de julgar-se e governar-se a si mesmos, de conduzir-se de uma determinada maneira, de comportar-se como sujeitos obedientes e dóceis" (Larrosa, 1994, p. 75).

O modelo elaborado por Larrosa para conduzir as análises da experiência de si implica a necessidade de considerar que os atos reflexivos estão associados ao domínio moral ${ }^{11}$, que é

[...] constituído por valores e normas, estruturado nas distinções axiológicas derivadas da distinção básica entre bom e mau, ou nas leis e normas de comportamento que têm a ver, em geral, com o dever. E aí, no domínio moral, a consciência se faz jurídica. O ver-se, o expressar-se e o narrarse no domínio moral se constituem como atos jurídicos da consciência. Isto é, atos nos quais a relação da pessoa consigo mesma tem a forma geral de julgar-se. (1994, p. 73)

O imperativo de julgar a si mesmo, portanto, está presente em todas as experiências que envolvem a auto-reflexão e tem um alcance prático bem maior, uma vez que visa à autotransformação que, por sua vez, vai afetar e regular os modos como o sujeito põe em operação novas formas de ver-se, de expressar-se e de narrar-se, produzindo assim, circularmente, uma lógica reguladora da conduta individual. O que passo a fazer, nesta seção, a partir deste ponto, é tratar de examinar como o RCN formula certos pressupostos e prescreve uma série de práticas, que buscam essas operações de autojulgamento e de autotransformação, em duas subseções que denominei: julgar-se e praticar-se.

${ }^{11}$ Larrosa (1994), seguindo Foucault, considera neste domíno moral também uma dimensão ética, ao mostrar como os atos jurídicos da consciência tanto podem se guiar pela lei e a norma quanto pelo estilo.

\section{Julgar-se}

É preciso fazer certas distinções e discutir alguns significados para estabelecer como se constituem os chamados "atos jurídicos da consciência", aqueles atos nos quais a pessoa realiza um julgamento sobre si mesma (Larrosa, 1994). Comecemos por isso que se chama critério. As experiências de si, no domínio ótico e discursivo, requerem que o sujeito refletidor sobre si mesmo, ao exteriorizar sua reflexão, faça-o na forma de uma autocrítica. Temos aí a interveniência de um critério ou padrão balizando o julgamento: "esse critério, seja ele imposto ou construído, absoluto ou relativo, é o que lhe permite estabelecer o verdadeiro ou o falso do eu, o bom e o mau, o belo e o feio" (idem, p. 74). O que ocorre é um julgamento de valor que se estriba na lei ou na norma. O juízo "implica uma decisão sobre o que é. [...] Por isso, o juízo é inseparável do ato que o diz. [...] E não há dizer sem um código no sentido ao mesmo tempo jurídico e lingüístico do termo" (idem, p. 74-75). Estabelecer um juízo é entender, com base em um código, qualquer situação particular como um caso. Formular um juízo implica tornar o caso sujeito à lei. "O juízo é, então, generalizante e singularizante ao mesmo tempo. Generalizante na medida em que despoja o acontecimento de sua particularidade e o constitui em caso. Singularizante na medida em que localiza, discerne, separa" (idem, p. 75).

As experiências de si propostas pelo RCN colocam em funcionamento um código normativo para balizar as ações que comportam o ver-se, o expressarse e o narrar-se. O que pretendem é levar as crianças a:

\footnotetext{
[...] desenvolver capacidades ligadas à tomada de decisões,

à construção de regras, à cooperação, à solidariedade, ao diálogo, ao respeito a si mesmas e ao outro, assim como desenvolver sentimentos de justiça e ações de cuidado para consigo e com os outros. (Brasil, 1998, v. 2, p. 43)
}

Embora as crianças sejam significadas pelo documento como "autônomas" ou "autolegisladoras" (Larrosa, 1994), todas as ações propostas no enuncia- 
do acima funcionam segundo um código com base no qual o sujeito se julga - como de resto todas as outras ações que compõem o que, neste trabalho, baseada em Foucault, defino como domínio moral. Ver as crianças desse modo, no entanto, não implica, a rigor, uma "contradição a ser resolvida". Esse modo de conceber as crianças e os modos correntes de submetê-las ao estrito domínio de algum código de regulação da conduta deriva do próprio processo de moralização que estou analisando. Deste modo, tematizar tal contradição não tem por objetivo resolvêla, mas apenas detectar nela a sua própria produtividade. A regulação da vida social não deixa ao acaso nem a tomada de decisões nem a construção de regras, muito menos o que toma por cooperação, solidariedade ou respeito ao outro. Ao tornar exigíveis tais condutas - cuja finalidade é tornar as crianças mais sensíveis ao que é considerado justo e desenvolver sentimentos de justiça -, o que o RCN, como um dispositivo, pretende é tornar os indivíduos capazes de julgarem-se e de autogovernarem-se:

Na brincadeira, [as crianças] vivenciam concretamente a elaboração e negociação de regras de convivência, assim como a elaboração de um sistema de representação dos diversos sentimentos, das emoções, das construções humanas. (Brasil, 1998, v. 2, p. 23)

Segundo Larrosa (1994, p. 77), na experiência de si está sempre implicada uma dimensão de juízo: "que pode ser estritamente jurídica (baseada na lei), normativa (baseada na norma), ou estética (baseada em critérios de estilo)". Voltemos, então, a fazer algumas distinções entre o que Foucault toma por lei, norma e estilo. A compreensão de tais significados é importante para percebermos algumas das nuanças da experiência de si propostas no documento que analiso. Enquanto os dispositivos regulativos baseados na lei fundam-se num modelo que estabelece uma partilha estrita entre permitido e proibido, funcionam por exclusão - estamos ou não conformes à lei, que não admite matizes ou transgressões, sob pena de eliminação do transgressor, nos casos mais extremos -, os dispositivos baseados na norma funcionam mediante uma concepção positiva de juízo. A regulação baseada na norma inclui e acomoda a todos. A lógica da normalização não exclui; com base no que é tomado como normal ela categoriza, classifica, para situar cada um nas gradações que vão da normalidade à anormalidade. A norma tem, assim, um caráter produtivo. Ao descrever-se o que é normal, este se torna normativo, estabelecendo o critério com base no qual os julgamentos se fazem positivos ou negativos (Larrosa, 1994). Rose (1997), ao analisar os sistemas de expertise da área $p s i$, mostra-nos de maneira bastante explícita como se dão as operações de normalização e quais os efeitos que produzem, ao utilizar a norma como critério de discernimento:

Existem variados modos de avaliar o eu, diagnosticando suas doenças, calibrando seus fracassos e avanços em termos das normas do intelecto ou da personalidade propostos pela Psicologia, dos repertórios de sentimentos e emoções disseminados pelas terapias, das formas de normalidade certificadas pelos proponentes dos sistemas comportamentais cognitivos. [...] É através dessas pequenas técnicas de si que a área psi penetra nossos modos de ser em um nível molecular, não formando apenas um contexto de significados, mas estruturando a própria textura de nossos modos de agir. (p. 244-245)

A idéia de "limites" ou "limitações" utilizadas nos fragmentos a seguir é característica da lógica normativa que se ancora num saber fixador de critérios "racionais" para o que é esperado das crianças - critérios estes considerados como objetivos - e num poder que constitui os princípios de regulação da conduta:

As brincadeiras e jogos envolvem a descoberta e a exploração de capacidades físicas e a expressão de emoções, afetos, sentimentos. Além de alegria e prazer, algumas vezes a exposição de seu corpo e de seus movimentos podem gerar vergonha, medo ou raiva. Isso também precisa ser considerado pelo professor para que ele possa ajudar as crianças a lidar de forma positiva com os limites e possibilidades do próprio corpo. (Brasil, 1998, v. 3, p. 37) 
É muito importante que o professor perceba os diversos significados que pode ter a atividade motora para as crianças. Isso poderá contribuir para que ele possa ajudálas a ter uma percepção adequada de seus recursos corporais, de suas possibilidades e limitações sempre em transformação, dando-lhes condições de se expressarem com liberdade e de aperfeiçoarem suas competências motoras.

(Brasil, 1998, v. 3, p. 39)

Foucault privilegiou nos seus últimos trabalhos os volumes 2 e 3 da História da sexualidade - outra forma de regulação da conduta moral que não se estriba nem na lei, nem na norma. As chamadas "práticas do eu" não se encontram sob o domínio legal ou normativo, não estão enquadradas no dispositivo jurídico, nem compõem o quadro das chamadas normas sociais; elas estão referidas muito mais a uma questão de estilo. Ao fazerem parte de uma ética positiva, não se pautam pelo dever, mas dirigem-se à elaboração da conduta. Ao estarem associadas a uma ética da existência, não têm pretensões a serem universais, constituem uma ética pessoal. O que esta ética pretende é tornar a existência uma obra com valores estéticos, uma obra de arte (Larrosa, 1994).

A experiência de si como prática de subjetivação tem o propósito de tornar os sujeitos culturais conscientes de sua incompletude ética, para assim poderem agir sobre si mesmos (Miller, 1993), utilizando-se de códigos morais - sejam eles os da lei, da norma ou do estilo. Assim, os modos de subjetivação incitam ou convidam os indivíduos a reconhecer constantemente suas obrigações morais. Tal é a substância do julgar-se: "a aplicação a si mesmo de critérios de juízo dominantes em uma cultura" (Larrosa, 1994, p. 77).

O RCN e a revista Criança, com seu acento nas atividades orientadas para a reflexão, apontam-nos claramente modelos de criança para orientar as operações de julgamento que põem em funcionamento. $\mathrm{O}$ que as pedagogias institucionais, com base nisso, deverão instaurar e consolidar é um processo de autotransformação, cujos modos de operar me proponho a analisar na seção seguir.

\section{Praticar-se}

As táticas de governamento e os processos de subjetivação dependem, para Rose (1998), de que a pessoa se reconheça ideal e potencialmente como um certo tipo de pessoa. O governo da alma, segundo ele, está associado ao "desconforto gerado por um julgamento normativo sobre a distância entre aquilo que somos e aquilo que podemos nos tornar e do incitamento oferecido para superar esta discrepância” (p. 44).

A tarefa de autotransformação é, neste sentido, tanto governada por técnicas propostas por experts na administração do eu - nas quais está sempre implicada uma dimensão jurídica - quanto pelos efeitos dos julgamentos que somos levados a constantemente fazer sobre a nossa própria conduta. Portanto, o modo pelo qual se vive a experiência de si comporta uma dimensão prática que busca o domínio do sujeito sobre si mesmo. Ao fazer a crítica das práticas que se voltam para a constituição pedagógica do domínio moral e do sujeito moral, Larrosa (1998) mostra-nos como em Foucault encontra-se toda uma problematização das formas de conceber estas práticas nos discursos educacionais "como espaços neutros de reflexão e diálogo" (idem, p. 49) e de compreender o sujeito envolvido nestas práticas "como simplesmente desenvolvendo suas capacidades de raciocínio moral e ação e construindo, sozinho, seus valores e normas" (Larrosa, 1998, p. 49).

Penso que tal raciocínio pode ser muito claramente articulado com as formulações do RCN apresentadas a seguir:

A possibilidade de desde muito cedo efetuarem escolhas e assumirem pequenas responsabilidades favorece o desenvolvimento da auto-estima, essencial para que as crianças se sintam confiantes e felizes. (Brasil, 1998, v. 2, p. 11)

[O trabalho institucional deve garantir oportunidades às crianças para que elas sejam capazes de] experimentar e utilizar os recursos de que dispõem para a satisfação de suas necessidades essenciais, expressando seus desejos, sentimentos, vontades e desagrados e agindo com progressiva autonomia. (Brasil, 1998, v. 2, p. 27) 
Os enunciados anteriores, que visam orientar as práticas pedagógicas, ao servir-lhes de referência tomam as atividades, os recursos e o ambiente pedagógico "como um espaço neutro de reflexão e comunicação onde a competência se desenvolve de uma forma natural" (Larrosa, 1998, p. 52). Como o que está em questão em tais enunciados são operações de poder, não interessa, do ponto de vista das tecnologias do eu postas em ação, a exemplo do que ocorre com as disciplinas, que as relações de poder aí implicadas se tornem explícitas. Os indivíduos infantis envolvidos em tais operações são por elas afetados e, ao mesmo tempo, produzem sua subjetividade: "O poder para afetar traz à luz, fala e obriga a falar, julga. O ver, o dizer e o julgar são, desse ponto de vista, parte das operações de constituição do que é afetado" (Larrosa, 1994, p. 79). Mas, trata-se aqui, também, de como o sujeito que se decifra e se julga efetua, baseado em tais ações, transformações sobre si mesmo. Como explicita o RCN:

Ao brincar, as crianças podem reconstruir elementos do mundo que as cerca com novos significados, tecer novas relações, desvincular-se dos significados imediatamente perceptíveis e materiais para atribuir-lhes novas significações, imprimir-lhes suas idéias e conhecimentos que têm sobre si mesma, sobre as outras pessoas, sobre o mundo adulto, sobre lugares distantes e/ou conhecidos. (Brasil, 1998 , v. 3, p. 171, grifos meus)

Apesar de oferecer muitos insights e sugestões sobre os modos de operar das práticas sociais, além de uma crítica à compreensão essencialista dos sujeitos envolvidos em tais práticas, o que falta a Foucault, segundo Larrosa (1998), é uma teoria da realização ou efetivação pedagógica das tecnologias do eu, que ele, Larrosa, se propõe a desenvolver. Se estamos interessados em examinar as técnicas de si como aqueles "procedimentos que, sem dúvida, existem em toda civilização, pressupostos ou prescritos aos indivíduos para fixar sua identidade, mantê-la ou transformá-la em função de determinados fins, e isso graças a relações de domínio de si sobre si ou do conhecimento de si por si"
(Foucault, 1997, p. 109), seria crucial entendermos o modo de funcionar das atividades pedagógicas como:

\section{[...] mecanismos práticos que criam, regulam e modificam uma experiência subjetiva de si mesmo. [...] Essa expe- riência subjetiva de si mesmo pode ser moldada a partir de um ponto de vista moral, na medida em que pode ser en- quadrada por um código normativo de conduta ou por um conjunto axiológico de valores a serem alcançados. (Larrosa, 1998, p. 64)}

Na proposta de Larrosa (1998), a realização desta experiência dá-se em práticas interacionais nas quais essas tecnologias funcionam ao modo de operadores simbólicos. Ao trabalharem em atividades de educação moral, as crianças aprendem a classificar as condutas que estão em discussão (esta é uma experiência basicamente discursiva) e a valorizar determinados comportamentos relacionados com as situações vividas. De tal sorte que elas aprendem significados de ordem moral e definem o seu próprio papel como agentes morais:

Nas leituras grupais, as crianças elaboram não somente os conteúdos comentados, mas estabelecem uma experiência de contato e diálogo com as outras crianças, desenvolvendo o respeito, a tolerância à diversidade de interpretações ou atribuição de sentido às imagens, a admiração, e dando uma contribuição às produções realizadas, por meio de uma prática de solidariedade e inclusão. (Brasil, 1998, v. 3, p. 105)

Em experiências como as descritas neste fragmento podem ocorrer muitas coisas e cada criança acabará por constituir uma série de significados próprios sobre a experiência vivida. Inspirando-me nas proposições de Larrosa (1998), vou fazer um pequeno exercício para mostrar algumas das possibilidades que antevejo. Cada criança estará implicada em estabelecer, em relação ao que é proposto, uma posição pessoal, um modo de ver-se naquela situação, tomando-se como um objeto a ser escrutinado: "qual a minha posição em relação ao que foi dito/produzido pelos meus colegas?" A experiência, assim, estará contri- 
buindo para que cada uma atribua um significado ao seu eu, como capaz de realizar apreciações, julgamentos, tomar posições etc. Ao participar efetivamente do que é proposto e ao ser convidada a exercitar o respeito e a tolerância, a criança é confrontada com um conjunto axiológico de valores, em que a regulação moral ocorre ao se estabelecer um compromisso pessoal com o procedimento, quando ela é instada a participar, contribuir, solidarizar-se.

Um outro exemplo de como operam as tecnologias do eu, que estão implicadas na constituição do sujeito moral, pode ser inferido com base no fragmento selecionado a seguir:

A partir [da leitura de histórias] ela pode estabelecer relações com a sua forma de pensar e o modo de ser do grupo social ao qual pertence. As instituições de Educação Infantil podem resgatar o repertório de histórias que as crianças ouvem em casa e nos ambientes que freqüentam, uma vez que essas histórias se constituem em rica fonte de informação sobre as diversas formas culturais de lidar com as emoções e com as questões éticas, contribuindo na construção da subjetividade e da sensibilidade das crianças. (Brasil, 1998, v. 3, p. 143)

Todas as experiências de constituição da subjetividade, na experiência pedagógica, exigem, segundo Larrosa (1998), algum tipo de relação pessoal com a matéria e algum tipo de exposição pessoal do eu. $\mathrm{Na}$ atividade proposta, as crianças são claramente colocadas como fonte de informações que dizem respeito ao domínio emocional e moral. Nas histórias que contam, no repertório de suas experiências pessoais postas a nu, nas perguntas que lhe são feitas e nas respostas que elas certamente darão às mesmas ocorre uma exibição pública do seu eu. "O sujeito pode se ver fora de si mesmo e pode se ver do ponto de vista dos outros" (idem, p. 61). Portanto, a identidade moral do sujeito e a ordem moral são constituídas por processos que estabelecem o controle sobre procedimentos e significados. As experiências pedagógicas que têm por finalidade a constituição do sujeito moral e da ordem moral se organizam de modo que valorizem a reflexão e a comunicação, ocultando seu propósito de transmissão de valores e a utilização que fazem de uma gramática de auto-interrogação e exibição pessoal.

Vale lembrar que as possibilidades de cooperação oferecidas pelo trabalho em grupo, em que as crianças conversam sobre o que fazem e se ajudam mutuamente, constituise num valioso recurso educativo. Além da troca de idéias, o confronto de pontos de vista que o trabalho em grupo propicia é um fator fundamental para que as crianças percebam que sua opinião é uma entre tantas outras possíveis, e para que possam assim integrar suas idéias às dos demais, numa relação de cooperação. (Brasil, 1998, v. 2, p. 40)

Talvez fosse pertinente lembrar aqui as palavras de Rose (1998, p. 43):

As tecnologias da subjetividade existem [...] numa relação simbiótica com aquilo que poderíamos chamar de "técnicas do eu". [...] Através da auto-inspeção, da autoproblematização, do automonitoramento e da confissão, avaliamos a nós mesmos de acordo com critérios que nos são fornecidos pelos outros. [...] pelos experts da alma. [...] A ironia é que nós acreditamos, ao transformar nossa subjetividade no princípio de nossas vidas pessoais, de nossos sistemas éticos e nossas avaliações políticas, que estamos livremente escolhendo a nossa liberdade.

$\mathrm{O}$ que pretendo ter enfatizado, ao longo deste texto, é que as crianças constituem-se como sujeitos morais dentro de um repertório de modos de falar, de interrogar e de avaliar a si mesmas, presentes nas sociedades em que vivem. Podemos considerar, portanto, que o RCN como um dispositivo pedagógico é um dos tantos meios inventados para a fabricação e gerenciamento do sujeito infantil. As operações de transformação supõem, segundo o referencial foucaultiano, o paulatino domínio do sujeito sobre si mesmo. A pessoa é constantemente incitada a dirigir a própria conduta, a estabilizar as suas ações, a ordenar e dar um sentido às suas escolhas (Larrosa, 1998). Portanto, autogovernar-se é, de certo modo, fabricar-se e inventar-se constantemente, ainda que dentro dos limi- 
tes e do controle exercido pelas relações de poder nas/ das quais participamos.

\section{Ao modo de um pós-escrito}

Ser livre não significa não acreditar em nada: significa é acreditar em muitas coisas - demasiadas para a comodidade espiritual da obediência cega; significa estar consciente de que há demasiadas crenças igualmente importantes e convincentes para a adoção de uma atitude descuidada ou niilista ante a tarefa da escolha responsável entre elas; e saber que nenhuma escolha deixaria o escolhedor livre da responsabilidade pelas suas conseqüências - e que, assim, ter escolhido, não significa ter determinado a matéria de escolha de uma vez por todas, nem o direito de botar sua consciência para descansar.

(Bauman. 1998, p. 249)

Tomo como inspiração estas palavras de Bauman, na epígrafe, para, neste momento, realizar uma advertência aos que me lêem. As análises que esbocei e apresentei neste texto, mediante uma inspiração foucaultiana, tiveram como objetivo pôr em evidência as conexões, as capilaridades e a solidariedade com que o poder se exerce nesse campo da educação da infância. O que ensaiei ao longo da investigação foi uma hipótese de leitura, uma entre tantas possíveis, que me permitiu "identificar as divisões, as distribuições e os jogos de poder, e também algumas das tramas discursivas que os constituíram” (Bujes 2001, p. 296). Não pretendi mais que isto. Esta não é uma produção que se proponha a pagar um tributo ao campo do qual eu provenho, a pedagogia, com a sua inarredável tendência à prescrição. E, ao comungar com o pensamento de François Ewald (apud Gore, 1998, p. 248), quando diz que "nós temos uma responsabilidade no que toca ao modo como exercitamos o poder: não [sendo] possível ignorar que poderíamos exercê-lo de forma diferente", quero enfatizar que este trabalho não é um empreendimento que se "reduz" a pensar e a analisar os dispositivos pedagógicos de produção da infância. Pensar, aqui, é, como diz Fischer (2002, p. 70), "exercitar um modo de vida, estudar e viver a própria vida presente". Assim, este é um experimento de risco que envolveu não apenas construir uma argumentação teórica, que pretendi sólida e bem fundamentada, para constituir o meu objeto de pesquisa. O que ensaiei também, ao longo deste percurso, foi uma prática militante, ainda que totalmente diferente de muitas que assumi, ao longo de minha carreira, na defesa da infância. Trata-se de um outro modo de falar deste presente (e de vivê-lo), que muitas vezes me "assombrou" e, por outras, me desafiou e instigou (Bujes, 2001).

Como disse Deleuze (2000, p. 220): "não cabe temer ou esperar, mas buscar novas armas". Creio que algumas delas estão aí, para que delas possamos fazer uso.

MARIA ISABEL EDELWEISS BUJES, doutora em educação pela Universidade Federal do Rio Grande do Sul, é professora da Universidade Luterana do Brasil, na qual coordena o Programa de Pós-Graduação em Educação. Atua na linha de pesquisa Trabalho, Identidade e Formação Docente e coordena o Laboratório de Estudos sobre Docência - poder e subjetivação, tendo especial interesse pelas questões relacionadas à infância e à educação infantil, em uma perspectiva culturalista. E-mail: mibujes@zaz.com.br

\section{Referências bibliográficas}

BAUMAN, Zygmunt, (1998). O mal-estar da pós-modernidade. Rio de Janeiro: Jorge Zahar Editor.

BRASIL, Ministério da Educação e do Desporto, Secretaria de Educação Fundamental, (1998). Referencial curricular nacional para a educação infantil. Brasília: MEC/SEF, 3 v.

BUJES, Maria Isabel E., (2002). O currículo da educação infantil como dispositivo pedagógico. Canoas: Ulbra/Programa de PósGraduação em Educação. Trabalho apresentado no IV Seminário de Pesquisa em Educação da Região Sul (Florianópolis: UFSC, nov. 2002).

(2001). Infância e maquinarias. Tese de doutorado. Faculdade de Educação, Universidade Federal do Rio Grande do Sul.

CORAZZA, Sandra M., (1998). História da infantilidade: a-vidaa-morte e mais-valia de uma infância sem fim. Tese de douto- 
rado. Faculdade de Educação, Universidade Federal do Rio Grande do Sul.

COSTA, Marisa.V., (org.) (2000). Mídia, magistério e política cultural. In: Estudos culturais em educação. Porto Alegre: Editora Universidade/UFRGS.

DEAN, Mitchell, (1999). Governmentality: power and rule in modern society. Grã-Bretanha: Sage Publications.

DELEUZE, Gilles, (2000). Conversações. Rio de Janeiro: Editora 34.

DOMINGUES, Ivan, (1996). A experiência do tempo. In: O fio e a trama. Belo Horizonte: UFMG: Iluminuras. p. $17-46$.

DU GAY, Paul. et al., (1997). Doing cultural studies: the story of the Sony Walkman. London: Sage/The Open University.

FERREIRA, Aurélio Buarque de Holanda, (1986). Novo dicionário da língua portuguesa. Rio de Janeiro: Nova Fronteira.

FISCHER, Rosa Maria B, (2002). Verdades em suspenso: Foucault e os perigos a enfrentar. In: COSTA, Marisa V. (org.). Caminhos investigativos II: outros modos de pensar e fazer pesquisa em educação. Rio de Janeiro: DP\&A.

FONSECA, Márcio Alves (1995). Michel Foucault e a constituição do sujeito. São Paulo: EDUC.

FOUCAULT, Michel, (1995). Tecnologias del yo. In: Tecnologias del yo y otros textos. Barcelona: Paidós. p. 45-94. , (1998). O uso dos prazeres. In: História da sexualidade. Rio de Janeiro: Graal, v. 2. , (1996). A verdade e as formas jurídicas. Rio de Janeiro: Nau. , (1997). A vontade de saber. In: História da sexualidade. Rio de Janeiro: Graal, v.1.

GORE, Jennifer, (1998). Disciplining bodies: on the contitunity of power relations in pedagogy. In: POPKEWITZ, Thomas, BRENNAN, Marie (eds.). Foucault's challenge. New York / London: Teacher's College Press. p. 231-251.

HARVEY, David, (1992). Condição pós-moderna. São Paulo: Loyola.
HUNTER, Ian, (1996). Assembling the school. In: BARRY, A., OSBORNE, T., ROSE, N. (eds.). Foucault and political reason. Chicago: The University of Chicago Press. p. 143-166.

LARROSA, Jorge, (1998). A construção pedagógica do sujeito moral. In: SILVA, T. T. da (org.). Liberdades reguladas. Petrópolis: Vozes. p. 46-75.

(1994). Tecnologias do eu e educação. In: SILVA, Tomaz T. da (org.). O sujeito da educação: estudos foucaultianos. Petrópolis: Vozes. p. 35-84.

LYOTARD, Jean-François, (1993). O pós-moderno explicado às crianças. Lisboa: Dom Quixote.

MILLER, Toby, (1993). The well-tempered self: citizenship, culture and the postmodern subject. Baltimore/London: The Johns Hopkins University Press.

PETERS, Michael, (2000). Pós-estruturalismo e filosofia da diferença. Belo Horizonte: Autêntica.

ROSE, Nikolas, (1997). Assembling the modern self. In: PORTER, Roy (ed.). Rewriting the self. London: Routledge. p. 224-248. , (1998). Governando a alma: a formação do eu privado. In: SILVA, T. T. da (org.). Liberdades reguladas. Petrópolis: Vozes. p. $30-45$.

(1996). Inventing our selves: psychology, power and personhood. Cambridge: Cambridge University Press.

USHER, Robin, EDWARDS, Richard, (1994). Postmodernism and education. London/New York: Routledge.

VEIGA-NETO, Alfredo, (1996). Olhares. In: COSTA, Marisa V. (org.). Caminhos investigativos: novos olhares na pesquisa em educação. Porto Alegre: Mediação. p. 19-35. , (2001). Governo ou governamento? Porto Alegre: UFRGS/FACED/PPGEdu. Texto digitado. , (org.) (1995). Crítica pós-estruturalista e educação. Porto Alegre: Sulina. 


\section{Resumos/Abstracts}

Jean-Louis Derouet

A sociologia das desigualdades em educação posta à prova pela segunda explosão escolar: deslocamento dos questionamentos e reinício da crítica

Analisa exemplarmente o caso francês, considerando inicialmente duas cronologias: uma longa, que se enraíza nos planos de educação da segunda metade do século XVIII, ligando a igualdade educativa à construção da unidade nacional e ao exercício da cidadania; outra curta, mais recente, que corresponde ao projeto da escola única e na qual a questão da mobilidade social é central. O tema das desigualdades educacionais aparece na França ao final dos anos de 1950. No entanto, a segunda explosão escolar, que ocorre a partir dos anos de 1980, e a ineficácia relativa das alternativas experimentadas no sistema educativo, entre elas a descentralização, exigem nova formulação do problema, em particular levando em conta a nova situação criada pelo desemprego e pelo aumento da exclusão.

Palavras-chave: sociologia da educação, desigualdades em educação.

The sociology of inequalities in education put to the test by the second school explosion: changing the questions and restarting the criticism The article analyses the French case considering initially two different chronologies: a long term one which is rooted in the educational plans of the second half of the $18^{\text {th }}$ century, linking educational equality with the construction of national unity and to the exercise of citizenship and, a more recent short-term chronology that corresponds to the project of the unitary school in which the question of social mobility is central. The theme of educational inequalities appears in France at the end of the 1950's. However the second school explosion which starts in the 1980's and the relative inefficiency of the alternatives tested in the educational system, amongst which decentralisation, demand a new formulation of the problem, taking into account the new situation created by unemployment and the increase in exclusion.

Key-words: education sociology, inequalities in education.

Maria Isabel Edelweiss Bujes

A invenção do eu infantil: dispositivos pedagógicos em ação

Este trabalho se insere no terreno das discussões que pretendem examinar as relações entre infância e poder. Tomando como seu foco principal o Referencial Curricular Nacional para a Educação Infantil (RCN), ele pretende apontar para as formas como operam os dispositivos de governamento da infância, a partir da racionalidade gover- namental moderna. A investigação, de inspiração foucaultiana, propõe-se a destacar também como os aparatos de poder/saber que se relacionam com a infância, com seus sistemas de enunciados verdadeiros, são produzidos no interior das relações pedagógicas. Neste artigo, realiza-se uma analítica de governamento da infância, a partir das proposições presentes no documento examinado. Destacam-se, neste exame, os modos de operar daquilo que Michel Foucault denominou de tecnologias $d a$ experiência de si ou tecnologias do eu. Associado às tecnologias políticas e às racionalidades de governamento, ressalta-se o RCN como dispositivo de produção das subjetividades infantis, uma vez que ele propõe a organização, a disseminação e o controle do saber que circula nas instituições de educação infantil.

Palavras-chave: educação infantil, tecnologias do eu, subjetividade infantil, dispositivos de poder.

Inventing the child's self: pedagogical dispositifs in action This work was conceived within the discussions that propose to analyse connections between power and early childhood. Choosing as its main focus the National Curriculum for Early Childhood Education - Referencial Curricular Nacional para a Educação Infantil (RCN) -, this study intends to problematise the ways governmental 
mechanisms operate to govern childhood. This research, inspired by Michel Foucault's ideas, seeks to show how mechanisms of power/knowledge concerning childhood are produced within pedagogical relationships. In this article, an analysis of the "government" of childhood is undertaken, examining propositions presented in the document and stressing the ways technologies of the self operate. Related to political technologies and governmental rationalities this work emphasises the $R C N$ as a mechanism that proposes to produce children's subjectivities and that aims to organise, impart and control the circulation of knowledge in early childhood institutions.

Key-words: early childhood education, children's subjectivities, technologies of the self, power mechanisms.

Nilma Lino Gomes

Trajetórias escolares, corpo negro e cabelo crespo: reprodução de estereótipos e/ou ressignificação cultural?

O trabalho estabelece uma articulação entre os processos educativos escolares e não-escolares e a construção da identidade negra. Discutem-se as representações e as concepções semelhantes, diferentes e complementares sobre o corpo negro e o cabelo crespo, construídas dentro e fora do ambiente escolar, a partir de lembranças de adolescentes e jovens negras entrevistadas durante a realização de uma pesquisa etnográfica sobre corpo e cabelo como ícones identitários em salões étnicos. Pretende-se compreender o significado social do cabelo e do corpo e os sentidos a eles atribuídos pela escola e pelos sujeitos negros entrevistados. $\mathrm{O}$ entendimento desse contexto revela que o corpo como suporte de construção da identidade ainda não tem sido uma temática privile- giada nos estudos sobre relações raciais e educação.

Palavras-chave: educação, identidade negra, corpo.

School trajectories, black skin and

Afro hair: reproduction of

stereotypes and/or cultural resignificance

This study establishes an articulation between school and non-school educational processes and the construction of Negro identity. It discusses the representations and similar, different and complementary conceptions about the Negro body and afro hair, constructed within and without the school environment, based on the memories of adolescent and young Negros interviewed during an ethnographic research on body and hair as identity icons in ethnic hairdressing salons. The intention is to understand the social significance of hair and body and the meanings attributed to them by the school and by the Negro subjects interviewed. The understanding of this context reveals that the body as a support for the construction of identity has not been a theme given prominence in studies on racial relations and education.

Key-words: education, negro identity, body.

Maria Helena Rodrigues Paes A questão da língua na escola indígena em aldeias Paresi de Tangará da Serra-MT

Os índios Paresi, de Tangará da Serra-MT, embora de grande apego aos elementos da sua cultura tradicional, vivem um processo de intensas relações com a sociedade envolvente, ressignificando seus hábitos tradicionais e os incorporados da cultura ocidentalizada, sendo a escolarização formal um instrumento essencial para transmissão dos códigos simbólicos da cultura ocidentalizada. Em um mo- mento de transição entre um modelo de escola tradicional para um modelo que atenda às especificidades da realidade local, este trabalho propõe uma reflexão, à luz dos estudos culturais, do discurso da valorização da língua portuguesa na rotina escolar, não entendendo esta opção como sobreposição aos valores da cultura tradicional, num processo de homogeneização, mas como uma ferramenta e um instrumento de poder, que visa marcar o lugar do Paresi na sociedade envolvente.

Palavras-chave: educação indígena, hibridização, linguagem.

The language question in the present dilemmas of the indigenous school in paresi villages in Tangará da Serra in the State of Mato Grosso

The Paresi Indians, from Tangará da Serra, in the State of Mato Grosso, although greatly attached to elements of their cultural tradition, experience a process of intense relations with the society by which they are surrounded, giving new meaning to their traditions and to those incorporated from the westernised culture. In this process, formal schooling has proved an essential instrument for the transmission of symbolic codes of westernised culture. In a phase of transition from a traditional school model to a model which attends the specificities of local reality, this paper proposes a reflection, in the light of cultural studies, on the discourse which values the use of Portuguese language in school routine, not understanding this option as an imposition on the values of the traditional culture as part of a process of homogenisation but as a tool and powerful instrument which aims to establish the place of the Paresi in the surrounding society.

Key-words: indigenous education, hybridisation, language. 